\title{
Effect of Magnetic Iron and Biofertilization Treatments on Wheat (Triticum aestivum L.) Productivity under Salinity Conditions
}

\author{
Howaida A. Maamoun and Mona M. Abdel Rahman El- \\ Shazly* \\ Plant Production Dept. and *Soil Fertility \& Microbiology \\ Dept., Desert Research Center, El-Matareya, Cairo, Egypt.
}

\begin{abstract}
$\mathbf{T}$ WO FIELD experiments were conducted at Ras-Sudr Research Station, South Sinai Governorate during two successive seasons, $2011 / 2012$ and 2012/2013 to study the effect of four levels of magnetic iron $(0,50,100$ and $150 \mathrm{~kg} / \mathrm{fed})$ and four biofertilization; control, Pseudomonas fluorescence and Rhizobium meliloti individual and mixed application on the yield parameters of wheat (Triticum aestivum L., cv. Sakha 94). Results revealed that increasing of the magnetic iron from 50 up to $150 \mathrm{~kg} /$ fed significantly increased all yield and yield components parameters; plant height $(\mathrm{cm})$, spike length $(\mathrm{cm})$, number of spikelets / spike, weight of 1000 grains $(\mathrm{g})$, biological yield $(\mathrm{kg} / \mathrm{fed})$, grain yield $(\mathrm{kg} / \mathrm{fed})$ and straw yield $(\mathrm{kg} / \mathrm{fed})$ compared with the control in each growing seasons. In single inoculation Rizobium gave better result than other treatments for all yield criteria in the two growing seasons. The effect of the interaction indicates that inoculating of the Rizobium, fertilized with $100 \mathrm{~kg}$ magnetic iron /fed resulted in the highest yield and yield components in the two growing seasons. Interaction resulted in between magnetic iron and biofertilization resulted in higher grain protein than the control. In addition, the percentage of $\mathrm{K}, \mathrm{K} / \mathrm{Na}$ ratio, $\mathrm{N}$, and grain protein of the Sakha 94 significantly increased in the two growing seasons. The analysis of the data collected during the study proved that there were statistically significant increases of wheat yield and yield components and some chemical contents due to different rates of magnetic treatments compared by the control which revealed decreases in the previously mentioned characters. Generally, the best treatments were $100 \mathrm{~kg}$ magnetic iron /fed and Rizobium meliloti. Both treatments were more effective in avoiding the adverse effects of soil salinity on wheat productivity compered to other treatments used.
\end{abstract}

Keywords: Magnetic iron, biofertilization, Rizobium meliloti, Pseudomonas fluorescence, Wheat, Grain yield.

Wheat is considered as the major cereal crop in the world in respect of the cultivated area and total production. It provides an almost $20 \%$ of food calories for people in the world as well as in Egypt (Al- Ansari, 2003). Increasing wheat production is the ultimate goal to reduce the wide gap between production and consumption. Wheat is generally classified to be moderately tolerant to salinity (Mass \& Hooffman, 1977). One million hectares of the irrigated areas in Egypt 
suffer from salinization problems and sodicity (FAO, 2005). The majority of salt-affected soils in Egypt are located in the Northern central part of the Nile Delta and on its Eastern and Western sides. About 900000 ha suffer from salinization problems in cultivated irrigated areas, $6 \%$ of Northern Delta region are salt-affected, $20 \%$ of the Southern Delta and Middle Egyptian region and $25 \%$ of the Upper Egypt region (FAO, 2008). Salinity is one of the serious environmental problems that cause reduction in plant growth and yield productivity in irrigated areas of arid and semi-arid regions of the world, the mechanism by which salt stress damage plants are still a discussing matter due to very complex nature of the salt stress in plants (Zhu, 2001). Plants growing in saline soil come across generally with major drawbacks; that is the increase in the osmotic stress due to high salt concentration of soil (Mesut et al., 2010). Plant productivity is considerably reduced due to osmotic inhibition of water uptake by roots or specific ion effects (Mayak et al., 2004). Salinity increases the uptake of $\mathrm{Na}^{+}$or decreases the uptake of $\mathrm{P}$ and $\mathrm{K}^{+}$which lead to nutritional imbalances (Yildirim et al., 2006).

Under South Sinai Governorate, agriculture suffered from both salt-affected soils beside saline underground brackish water which contains varying amounts of dissolved salts used for irrigation. Under Egyptian condition, application of magnetic technologies is a new concept. Overcoming the negative effect of salinity, using magnetic iron $\left(\mathrm{Fe}_{3} \mathrm{O}_{4}\right)$, is one of the most important factors affecting plant growth. It has a black or brownish-red color and it is one of two natural row rocks in the world that is naturally magnetic (Mansour, 2007). Application of a magnetic iron has shown to increase plant height, yield and its components (Sharma et al., 2003). Agro minerals include geological materials that contain one or more recognized plant nutrients and so-called 'rock fertilizers' (Leonardos et al., 2000). Iron ores often contain impurities, undesirable chemical components such as phosphorous, sulfur, sodium, potassium (alkalis), alumina, silica and sometimes titanium (Ismail et al., 2010). Application of magnetic iron increased vegetative growth, yield on pepper plant grown under saline irrigation conditions (Taha et al., 2011). It also includes rocks and minerals that improve the physical status of soils. The use of rocks and minerals as low-cost, locally available geological nutrient resources for agricultural development is not new. Moreover, rocks and minerals are used in crop production systems for several purposes, among them improving soil fertility, correcting the $\mathrm{pH}$ of soil, conserving nutrients and water (Podleśny et al., 2005).

The use magnetic iron in agricultural production is mainly to reclaim alkaline sodic soils and it has been tested as an inexpensive material to correct $\mathrm{Fe}$ deficiencies in calcareous soils (Barrau \& Berg, 1977). It enriched manure to improve a good source for iron on alkaline soils (Bangar et al., 1985). Anonymous (2006) reported that many benefits to crop growth can result from addition of the natural mineral product i.e., magnetic iron including improved soil structure, increased soil organic matter, improved water properties and became more energy and vigor and this known as "Magneto biology", improved

Egypt. J. Agron . 36, No.1 (2014) 
water - holding capacity and cation exchange capacity, increasing water retention by soil and this helps plant growth, moderation of soil temperature, improved crop nutrition from macro and microelements (Taha et al., 2011). Moreover, the magnetic process separates all chlorine, toxic and harmful gases from soils so increases salt movement and solubility of nutrients (Podleśny et al., 2005). If it is known that a real shortage of Fe exists in the soil and is causing deficiency symptoms, the addition of iron fertilizer or other readily available iron sources can correct the shortage.

Biofetilization are good source of nutrients and increase organic matter in soil. It may not only activate $\mathrm{N}_{2}$-fixation but also growth and production, yield level as well as producing of the growth regulators such as auxin, cytokine, gibberellins,...etc., that increases the grain yield (El-Kased et al., 1996). Rhizobium is an important symbiotic for legumes but it plays an important role with non-legumes by producing growth hormones. The first important step for producing growth hormone is root colonization of beneficial bacteria with plants (Kloepper \& Beauchamp, 1992). Rhizobia are able to colonize and survive in the rhizosphere of the non-legumes plant to act as plant growth promoting rhizobacteria (PGPR) in the rhizosphere of nonhost legumes and non-legumes (Wiehe \& Höflich, 1995). Plant growth promoting rhizobacteria (PGPR) is a group of free-living bacteria that colonize the rhizosphere and exert a beneficial impact on plant health and soil fertility. PGPR can directly facilitate the plant growth in several ways such as syntheses of phytohormones, siderophores production, solubilization of mineral phosphate and synthesis of the enzyme ACC-deaminase (Zahir et al., 2010). Microbial siderophores play an important role in the biocontrol of some soil-borne plant diseases and in plant iron nutrition; rhizobia produce different type of siderophores (Guerinot, 1991).

To overcome iron starvation, B. japonicum can utilize its own siderophores and those produced by other organisms (Plessner et al., 1993). Efforts on the interaction of rhizobia with non-legumes have increased during the previous couple of decades, and it has been established that roots of non-legumes could also be associated with rhizobia, devoid of effective nodule formation. Also, several mechanisms e.g., phytohormones production (Zahir et al., 2010), siderophore production (Meyer, 2000) and increased availability of insoluble phosphorus (Fatima et al., 2006) have been proposed by which Rhizobia can stimulate the growth of non-legumes directly and indirectly via suppressing or eliminating deleterious microbes by producing antibiotics (Antoun \& Prevost, 2000). Biofertilization technology is practiced for increasing agricultural production, to limit the use of chemical fertilizers and pollution of environment through seed inoculation by different types of bacteria (Abd El-Ghany, 1994). Rhizobium colonization in non-legumes such as wheat, Brassica and Arabidopsis thaliana does not require the Rhizobium nodulation genes which are involved in the infection and nodulation of legume roots (Hafeez et al., 2005). Efforts at extending $\mathrm{N}_{2}$-fixing ability to important non-leguminous crops such as cereals have long been a major goal of researchers in the field of biological nitrogen fixation. Making cereals self-sufficient in $\mathrm{N}$ nutrition would be of great 
benefit to resource-poor farmers in Africa (Viviene \& Dakora, 2004). One approach for achieving this goal has involved the isolation and characterization of $\mathrm{N}_{2}$-fixing bacteria from a variety of wild and cultivated cereal crops (Stoltzfuz et al., 1997). Plant inoculation with Rizobium for example, promoted higher uptake of researchers in $\mathrm{NO}_{3}^{-}, \mathrm{K}^{+}$and $\mathrm{H}_{2} \mathrm{PO}_{4}^{-}$in corn, sorghum and wheat, leading to higher crop yields perhaps rhizobia produce various metabolites such as auxins, cytokinins, riboflavin and vitamins (Dakora, 2003). The main object of this study is an attempt for reducing the effect of magnetic iron and biofertilization treatments on wheat productivity under saline stress conditions at Ras-Sudr region.

\section{Material and Methods}

Two field experiments were carried out at Ras-Sudr Agricultural Experimental Station of Desert Research Center, South Sinai Governorate in Egypt during 2011/2012 and 2012/2013 to study the effect of four levels of magnetic iron $(0,50,100$ and $150 \mathrm{~kg} / \mathrm{fed}$. Hectare $=2.38$ fed) and four biofertilization treatments; control, Pseudomonas fluorescence and Rhizobium meliloti individual and mixed application on wheat (Triticum aestivum L. cv. Sakha 94). The experiments were laid in a split plot design with four replications, where, biofertilization were allocated in main plots and magnetic iron occupied the sub-plots. Sakha 94, used which was obtained from the Agriculture Research Center, Giza, Egypt. The magentic iron treatments were added to the soil once during the plant life in a powder form before sowing. The used magnetic iron contained $3.72 \% \mathrm{SiO}_{2}, 14.90 \% \mathrm{TiO}_{2}, 1.23 \%, \mathrm{Al}_{2} \mathrm{O}_{3}, 76.56 \%$ $\mathrm{Fe}_{2} \mathrm{O}_{3}, 0.35 \% \mathrm{MnO}, 1.21 \% \mathrm{MgO}, 0.45 \% \mathrm{CaO}, 0.42 \% \mathrm{Na}_{2} \mathrm{O}, 0.05 \% \mathrm{~K}_{2} \mathrm{O}, 0.07 \%$ $\mathrm{P}_{2} \mathrm{O}_{5}, 0.09 \% \mathrm{Cl}$ and $0.05 \% \mathrm{SO}_{3}$. It was obtained from "El- Ahram Company for Mining and Natural Fertilizers" (ECMNF), Giza. Egypt. Rhizobium and Pseudomonas fluorescence were isolated from nodules of vegetable pea at RasSudr station. Pink, healthy and undamaged nodules were selected, then in field experiments wheat grain was planting and inoculated by biofertlization after ten days on soil under Ras-Sudr conditions (Abd El-Ghany, 1994). Table 1 presented the physical and chemical analysis of the soil site.

TABLE 1. Some physical and chemical analysis of the experimental site.

\begin{tabular}{|c|c|c|c|c|c|c|c|c|c|c|c|}
\hline \multirow[t]{2}{*}{ Season } & \multicolumn{3}{|c|}{ Particle size (\%) } & \multirow{2}{*}{$\begin{array}{c}\text { Texture } \\
(\%)\end{array}$} & \multirow{2}{*}{$\begin{array}{c}\text { Field } \\
\text { capacity } \\
(\%)\end{array}$} & \multirow{2}{*}{$\begin{array}{c}\text { Wielting } \\
\text { point } \\
(\%)\end{array}$} & \multirow{2}{*}{$\begin{array}{c}\text { Available } \\
\text { water } \\
(\%)\end{array}$} & \multirow{2}{*}{$\begin{array}{c}\text { EC } \\
d s / m\end{array}$} & \multirow{2}{*}{$\begin{array}{r}\text { O.M } \\
(\%)\end{array}$} & \multirow{2}{*}{$\begin{array}{c}\mathrm{CaCO}_{3} \\
(\%)\end{array}$} & \multirow[t]{2}{*}{ pH } \\
\hline & Sand & Silt & Clay & & & & & & & & \\
\hline $2011 / 12$ & 74.47 & 10.90 & 14.63 & S. loam & 18.45 & 10.25 & 8.20 & 7.80 & 0.28 & 52.40 & 7.74 \\
\hline $2012 / 13$ & 76.60 & 9.55 & 13.85 & S. loam & 17.75 & 9.80 & 7.95 & 6.50 & 0.15 & 46.60 & 7.89 \\
\hline \multicolumn{6}{|c|}{ Soluble Cations ( $\mathrm{meq} / \mathbf{1 0 0 g})$} & \multicolumn{6}{|c|}{ Soluble Anions ( meq/ 100g) } \\
\hline Season & $\mathrm{K}^{+}$ & \multicolumn{2}{|c|}{$\mathrm{Na}^{+}$} & $\mathrm{Mg}^{++}$ & $\mathrm{Ca}^{++}$ & $\mathrm{SO}^{--}$ & $\mathrm{Cl}^{-}$ & \multicolumn{2}{|c|}{$\mathrm{HCO}_{3}$} & \multicolumn{2}{|c|}{$\mathrm{CO}^{-}$} \\
\hline $2011 / 12$ & 2.30 & \multicolumn{2}{|c|}{40.50} & 9.20 & 26.00 & 29.00 & 45.50 & \multicolumn{2}{|c|}{3.50} & \multicolumn{2}{|c|}{0.00} \\
\hline $2012 / 13$ & 1.30 & \multicolumn{2}{|c|}{32.70} & 8.30 & 22.70 & 25.50 & 37.50 & \multicolumn{2}{|c|}{2.00} & \multicolumn{2}{|c|}{0.00} \\
\hline \multicolumn{12}{|c|}{ Extractable available elements (ppm) } \\
\hline Season & $\mathrm{N}$ & $\mathrm{P}$ & $\mathrm{K}$ & $\mathrm{Fe}$ & $\mathrm{Mn}$ & $\mathrm{Zn}$ & $\mathrm{Cu}$ & $\mathrm{Ni}$ & $\mathrm{Pb}$ & \multicolumn{2}{|c|}{$\mathrm{Cd}$} \\
\hline $2011 / 12$ & 18 & 7.5 & 50 & 6.98 & 4.86 & 2.21 & 1.01 & 0.33 & 0.22 & \multicolumn{2}{|c|}{0.09} \\
\hline $2012 / 13$ & 11 & 5.4 & 35 & 5.8 & 3.77 & 1.77 & 0.94 & 0.25 & 0.15 & \multicolumn{2}{|c|}{0.08} \\
\hline
\end{tabular}

$\mathrm{EC}=$ Electeric conductivity, O.M= Organic matter.

Egypt. J. Agron. 36, No.1 (2014) 
The area of each plot was $2 \times 3 \mathrm{~m}=6 \mathrm{~m}^{2}$, which had 4 rows $(3 \mathrm{~m}$ length, $50 \mathrm{~cm}$ apart.). Grains were sown in November, $20^{\text {th }}, 2011$ in the first season and November, $24^{\text {th }}, 2012$ in the second season at seeding rates of $80 \mathrm{~kg} / \mathrm{fed}$, for the two seasons.

The recommended cultural practices of growing wheat plants were applied. Different soil samples were collected from different sites of Ras Sudr used for isolation, about eleven Pseudomonas isolates were obtained as shown in Table 2. Cultures of Pseudomonas isolates were purified by successive streaking on King's medium B was based on the formulation of Murray et al. (2003). Microscopically examination was carried out to check the purity of cultures. The purified Pseudomonas isolates were tested for their phosphate dissolving efficiency quantitatively and qualitatively according to De Freitas et al. (1997), also, siderophore production (Reeves et al., 1983) and salicylic acid production (Meyer et al., 1992). The most active fluorescent Pseudomonas isolates with phosphate dissolving activity, siderophore production and Salycilic acid production were identified using Bergey's (Table 3).

TABLE 2. Phosphate solubilization, Siderophore and Salicylic acid production by Pseudomonas isolates.

\begin{tabular}{|l|c|c|c|}
\hline $\begin{array}{l}\text { Pseudomonas } \\
\text { isolates }\end{array}$ & $\begin{array}{c}\text { Phosphate solubilization } \\
(\mathbf{c m})\end{array}$ & $\begin{array}{c}\text { Siderophores } \\
(\boldsymbol{\mu} \mathbf{g} / \mathbf{m l}, \mathbf{4 1 0} \mathbf{~ n m})\end{array}$ & $\begin{array}{c}\text { Salicylic acid } \\
(\boldsymbol{\mu g} / \mathbf{m l}, \mathbf{5 2 7} \mathbf{~ n m})\end{array}$ \\
\hline 1 & 0.7 & 36 & 23 \\
\hline 2 & 1.4 & 31.4 & 28.1 \\
\hline 3 & 1.0 & 40.2 & 35 \\
\hline 4 & 0.8 & 39.2 & 36 \\
\hline 5 & 1.6 & 31.9 & 27.3 \\
\hline 6 & 1.5 & 44.8 & 24.1 \\
\hline 7 & 1.1 & 38 & 26 \\
\hline 8 & 2.4 & 57.9 & 31.5 \\
\hline 9 & 1.3 & 43 & 37 \\
\hline 10 & 2.0 & 48 & \\
\hline 11 & 0.9 & 51 & \\
\hline
\end{tabular}

Locally isolated Rhizobium spp. was maintained at $4^{\circ} \mathrm{C}$ on yeast extract mannitol agar (YEMA). Biochemical activities of studied microbial isolate to determine; the ability of the tested microbial isolates to produce biochemical activities was evaluated under in vitro conditions, through determination of their efficiency for growth regulators production (Rizzolo et al., 1993) and antibiotic production (Jarlier et al., 1996) (Table 4). Soil samples of wheat rhizosphere were collected in both seasons and analyzed for microbial determinations. Total microbial counts were determined on Bunt and Rovira medium (Nautiyal, 1999) using the decimal plate method technique. $\mathrm{CO}_{2}$ evolution was measured according to Anderson (1982). The most probable number (MPN) of Pseudomonades was determined after incubating the tubes at $30 \pm 2^{\circ} \mathrm{C}$ for $48 \mathrm{~h}$ on King's B medium (Bergey's, 1994). Estimates of number of Pseudomonades by MPN technique were calculated using Cochran's table. At harvest (after 160 days) select randomized ten plants from each plots to determine: plant height $(\mathrm{cm})$, spike length $(\mathrm{cm})$, number 
of spikelets / spike, weight of 1000 grains $(\mathrm{g})$ and from $1 \mathrm{~m}^{2}$ to biological yield ( $\mathrm{kg} / \mathrm{fed})$, grain yield ( $\mathrm{kg} / \mathrm{fed})$ and straw yield ( $\mathrm{kg} / \mathrm{fed})$. In addition, samples were chosen for the chemical analysis determining the percentage of potassium, sodium and $\mathrm{K} / \mathrm{Na}$ ratio (Page, 1982). Nitrogen and protein ( $\mathrm{N}$ X6.25) values were calculated as described by A.O.A.C. (1995). Data were statistically analyzed by using analysis of variances according to Snedecor \& Cochran (1990) and means were grouped by LSD test at the 5\% probability level.

\section{Results and Discussion}

Isolation and characterization of fluorescent Pseudomonas isolates

Different soil samples were collected from the rhizosphere of different crops for Pseudomonas isolation; eleven bacterial isolates were isolated, purified and examined for their activities to dissolve phosphate qualitative by Mean diameter of lyses (cm) (De Freitas et al., 1997), production of siderophore (Reeves et al., 1983) and production of Salicylic acid (Meyer et al., 1992) (Table 2).

\section{Identification of Pseudomonas isolate}

The most active isolate no. (8), was completely identified according to Bergey's Manual of Determinative Bacteriology (1994). The morphological and physiological characters presented in Table 3. Selected Pseudomonas isolate was found to belong to $P$. fluorescens.

TABLE 3. Identification of Pseudomonas isolates no.4.

\begin{tabular}{|c|c|}
\hline Biochemical reactions & Results \\
\hline \multicolumn{2}{|l|}{ Morphological character: } \\
\hline Shape & Short rod \\
\hline Motility & Motile \\
\hline Gram reaction & Gram negative \\
\hline $\mathrm{KOH}$ solubility test & + \\
\hline \multicolumn{2}{|l|}{ Physiological character : } \\
\hline Pyoverdin production & + \\
\hline Pyocyanin production & + \\
\hline Oxidase reaction & + \\
\hline Starch hydrolysis & - \\
\hline Hydrogen sulphide production & + \\
\hline Catalase production & + \\
\hline Utilization of : Glucose & + \\
\hline Trehalose & - \\
\hline D-Mannose & + \\
\hline
\end{tabular}

Biochemical activities of Pseudomonas fluorescens and Rhizobium spp.

Microbes under study known to produce a number of secondary metabolites which may affect growth, health of plants, and the relationships between rhizosphere soil microorganisms and plant growth regulators (quantitative (HPLC) $/ \mu \mathrm{g} / \mathrm{ml}$ ) and antibiotic production. Table 4 shows the biochemical activities of the Rhizobium spp. and Pseudomonas fluorescens used in the trial for production of plant hormones and antibiotics. As shown in Table 4

Egypt. J. Agron . 36, No.1 (2014) 
microorganisms exhibited biochemical and hormonal activities in vitro that could result in beneficial action in the field (El-Saidy \& Abd El-Hai, 2011).

TABLE 4. Biochemical activities of microbial isolates.

\begin{tabular}{|l|c|c|}
\hline Hormonal activity $\boldsymbol{\mu g} / \mathbf{m l}$ & P. fluorescens & Rhizobium \\
\hline IAA & 10.2 & 2.7 \\
GA3 & 1.95 & 3.29 \\
Cytokinine & 18.39 & 12.4 \\
\hline \multicolumn{2}{|c|}{ Antibiotic reduction(mm) } \\
\hline Escherchia coli & 23 & - \\
Salmonella typhi & 27 & - \\
Fusarium oxysporum & 32 & - \\
Rhizoctonia solani & 24 & - \\
\hline
\end{tabular}

\section{Microbial determinations in wheat rhizosphere}

\section{Total microbial counts}

Initial total microbial counts in Ras Sudr soil was $24 \times 10^{5} \mathrm{cfu} / \mathrm{g}$ dry soil. Data in Table 5 showed that the counts tended to increase in all treatments compered to the control. Total microbial counts proved an increase in vegetative stage of wheat plant growth followed by harvesting in both growing seasons. Also, interaction treatment between P.flouresence inoculation, Rhizobium and magnetic iron application produced the highest total microbial counts as compared with other treatments and control. These results agreed with Abd El-Ghany et al. (1997).

\section{$\mathrm{CO}_{2}$ evolution}

The generation of carbon dioxide $\left(\mathrm{CO}_{2}\right)$ was determined as an indication of the biological activity in plant rhizosphere. Results in Table 5 clearly showed that mixed treatment with $P$. fluorescens inoculation, Rhizobium and magnetic iron application gave high rate of $\mathrm{CO}_{2}$ evolution compared to all other treatments. Data of $\mathrm{CO}_{2}$ evolution were almost in harmony with those of total microbial counts discussed before. These results agreed with Visser \& Dennis (1992).

\section{Pseudomonas densities}

The initial Pseudomonas densities in Ras Sudr were $3.8 \times 10^{3} \mathrm{cfu} / \mathrm{gm}$ dry soil. Data recorded in Table 5 proved a marked increase in Pseudomonas densities in first and second season. The increase in Pseudomonas densities was higher in the second season than the first one, and the increase was higher vegetative stage but decreased at harvest. The densities under interaction treatment of P.flouresence, Rhizobium and magnetic iron application recorded the highest density. The highest increase in Pseudomonas densities were obtained by using the interaction treatment with magnetic iron application treatments $(0,50,100$ and $150 \mathrm{~kg} / \mathrm{fed}$, respectively). The promoting effect due to the application of $P$. flouresence not only to the production of organic acid and siderophore which increased the availability of iron uptake but also to the production of plant growth promoting 
substances and antimicrobial substances as well which increase soil fertility, microbial communities and plant growth (Yadav et al., 2007). Anandaraj \& Leema (2010) confirmed that, combined inoculation increased the population of total bacteria, Rhizobium sp. and Pseudomonas fluorescens over not inoculated control indicating the ability of the introduced microorganisms to establish them in the rhizosphere.

TABLE 5. Effect of interaction between magnetic iron and biofertilization on biological activity in wheat rhizosphere.

\begin{tabular}{|c|c|c|c|c|c|c|c|}
\hline \multirow{3}{*}{$\begin{array}{l}\text { Biofertilizer } \\
\text { treatment }\end{array}$} & \multicolumn{7}{|c|}{ First season } \\
\hline & \multirow{2}{*}{$\begin{array}{l}\text { Magnetic } \\
\text { iron } \\
(\mathrm{kg} / \mathrm{fed})\end{array}$} & \multicolumn{2}{|c|}{$\begin{array}{c}\mathrm{TC} \times 10^{5} \mathrm{cfu} / \mathrm{gm} \\
\text { dry soil }\end{array}$} & \multicolumn{2}{|c|}{$\begin{array}{c}\mathrm{CO}_{2} \mathrm{mgCO}_{2} / 100 \\
\mathrm{~g} \text { dry soil } / 24 \mathrm{~h}\end{array}$} & \multicolumn{2}{|c|}{$\begin{array}{c}\text { Ps } \times 10^{3} \text { cells } / g m \\
\text { dry soil }\end{array}$} \\
\hline & & Veg. & Harv. & Veg. & Harv. & Veg. & Harv. \\
\hline \multirow{4}{*}{$\begin{array}{l}\text { Without } \\
\text { inoc. }\end{array}$} & Control & 37 & 34 & 16.3 & 15.7 & 4.1 & 3.9 \\
\hline & 50 & 42 & 38 & 21 & 19.8 & 6.4 & 5.3 \\
\hline & 100 & 43 & 40 & 24 & 20.6 & 7 & 6.1 \\
\hline & 150 & 45 & 41 & 27 & 23 & 7.8 & 6.8 \\
\hline \multirow[t]{4}{*}{ P.fluorescens } & Control & 31 & 28 & 17 & 16.1 & 4.5 & 4.2 \\
\hline & 50 & 52 & 49 & 24.1 & 22 & 7.2 & 6.3 \\
\hline & 100 & 60 & 57 & 25 & 22.6 & 9.3 & 8 \\
\hline & 150 & 63 & 59 & 25 & 23 & 9.5 & 8.7 \\
\hline \multirow[t]{4}{*}{ Rhizobium } & Control & 34 & 31 & 16 & 15.2 & 4.8 & 4.1 \\
\hline & 50 & 56 & 51 & 27 & 26 & 8.2 & 7.5 \\
\hline & 100 & 64 & 57 & 29 & 27.3 & 9 & 8.4 \\
\hline & 150 & 66 & 59 & 30 & 28 & 9.6 & 9.1 \\
\hline \multirow{4}{*}{$\begin{array}{l}\text { Mix } \\
\text { (P.fluorescens } \\
+ \text { Rhizobium })\end{array}$} & Control & 36 & 33 & 18 & 16.5 & 5.2 & 4.7 \\
\hline & 50 & 63 & 59 & 31 & 28.4 & 9.3 & 8.5 \\
\hline & 100 & 71 & 65 & 33 & 30 & 9.8 & 8.9 \\
\hline & 150 & 77 & 68 & 35 & 31.7 & 10.3 & 9.4 \\
\hline \multicolumn{2}{|l|}{ L.S.D at 5\% } & \multicolumn{2}{|c|}{1.62} & \multicolumn{2}{|c|}{0.139} & \multicolumn{2}{|c|}{0.53} \\
\hline \multicolumn{8}{|c|}{ Second season } \\
\hline \multirow{4}{*}{$\begin{array}{l}\text { Without } \\
\text { inoc. }\end{array}$} & Control & 43 & 38 & 18.1 & 16.4 & 4.7 & 4.2 \\
\hline & 50 & 48 & 45 & 23 & 19.6 & 7.2 & 6.3 \\
\hline & 100 & 51 & 49 & 27 & 22.9 & 8.6 & 8.1 \\
\hline & 150 & 53 & 50 & 30 & 26 & 9 & 8.3 \\
\hline \multirow[t]{4}{*}{\begin{tabular}{|l|} 
P.fluorescens \\
\end{tabular}} & Control & 38 & 35 & 19 & 17.2 & 5.1 & 4.8 \\
\hline & 50 & 57 & 52 & 28.6 & 25.3 & 7.9 & 7.1 \\
\hline & 100 & 66 & 61 & 31.8 & 28.9 & 9 & 8 \\
\hline & 150 & 69 & 65 & 33 & 30.4 & 10.3 & 9.8 \\
\hline \multirow[t]{4}{*}{ Rhizobium } & Control & 37 & 34 & 18.7 & 17.6 & 5.6 & 5.1 \\
\hline & 50 & 56 & 50 & 32.5 & 30.4 & 9.4 & 8.5 \\
\hline & 100 & 64 & 59 & 34 & 32.5 & 10.2 & 9.6 \\
\hline & 150 & 66 & 61 & 37 & 35.1 & 11 & 10.4 \\
\hline \multirow{4}{*}{\begin{tabular}{|l|} 
Mix \\
(P.fluorescens \\
+ Rhizobium $)$
\end{tabular}} & Control & 36 & 32 & 19.2 & 18 & 5.5 & 5.1 \\
\hline & 50 & 63 & 58 & 33 & 31.7 & 9.8 & 9.5 \\
\hline & 100 & 71 & 67 & 37 & 34.9 & 10.7 & 10.5 \\
\hline & 150 & 77 & 68 & 39 & 36.4 & 11.8 & 10.5 \\
\hline \multicolumn{2}{|l|}{ L.S.D at (5\%) } & \multicolumn{2}{|c|}{$\frac{1}{1.44}$} & \multicolumn{2}{|c|}{$\begin{array}{l} \\
\end{array}$} & \multicolumn{2}{|c|}{0.71} \\
\hline
\end{tabular}

Tc: total microbial count

Ps: Pseudomonas fluorescens

Egypt. J. Agron. 36, No.1 (2014) 


\section{Wheat yield and yield components}

Effect of magnetic iron on wheat yield and yield components

Data in Table 6, show that increasing magnetic iron levels from 50 up to 150 $\mathrm{kg} / \mathrm{fed}$, wheat yield and its components characters increased significantly :plant height $(\mathrm{cm})$, spike length $(\mathrm{cm})$, number of spikelets / spike, weight of 1000 grains $(\mathrm{g})$, biological yield $(\mathrm{kg} / \mathrm{fed})$, grain yield $(\mathrm{kg} / \mathrm{fed})$ and straw yield $(\mathrm{kg} / \mathrm{fed})$ in the two growing seasons. Results of the current study demonstrate that magnetic treatments improved wheat yield and its components compared to the control. It was also clear that all previously mentioned characters were progressively increased with increasing the dose of magnetite, where the highest significant increases in yield parameters obtained under the highest magnetite dose $(150 \mathrm{~kg} / \mathrm{fed})$ compared to control plants. Magnetic treatments may affect phytohormone production leading to improved cell activity and plant growth (Maheshwari, 2009). The present results are in harmony with those of Sudhakar et al. (2002), Abd El-Al (2003) and Esitken \& Turan (2004), also to that obtained by De Souza (2005) whom reported that magnetic treatments led to a remarkable increase in plant root and stem length as well as fresh and dry weights during the nursery period of tomato plant.

TABLE 6. Effect of magnetic iron on wheat yield and its components in the two growing seasons.

\begin{tabular}{|c|c|c|c|c|c|c|c|}
\hline $\begin{array}{l}\text { Characters } \\
\text { Magnetic } \\
\text { Iron } \\
(\mathrm{kg} / \mathrm{fed})\end{array}$ & $\begin{array}{c}\text { Plant } \\
\text { height } \\
(\mathrm{cm})\end{array}$ & $\begin{array}{l}\text { Spike } \\
\text { length } \\
(\mathrm{cm})\end{array}$ & $\begin{array}{c}\text { No. of } \\
\text { spikelets/ } \\
\text { spike }\end{array}$ & $\begin{array}{l}\text { 1000- } \\
\text { grains } \\
\text { weight } \\
\text { (g) }\end{array}$ & $\begin{array}{c}\text { Biological } \\
\text { yield } \\
\text { (kg /fed) }\end{array}$ & $\begin{array}{c}\text { Grain } \\
\text { yield } \\
\text { (kg /fed) }\end{array}$ & $\begin{array}{c}\text { Straw } \\
\text { yield } \\
(\mathbf{k g} / \mathbf{f e d})\end{array}$ \\
\hline \multicolumn{8}{|c|}{ 2011/2012 season } \\
\hline 0 & 68.43 & 11.72 & 16.63 & 33.83 & 1146.57 & 819.60 & 326.97 \\
\hline 50 & 77.84 & 12.7 & 17.66 & 39.33 & 2334.93 & 1145.24 & 1189.69 \\
\hline 100 & 86.01 & 13.79 & 18.52 & 45.33 & 3757.63 & 1396.95 & 2360.68 \\
\hline 150 & 87.58 & 14.02 & 18.75 & 47.25 & 4210.14 & 1554.47 & 2655.67 \\
\hline LSD $_{5 \%}$ & 1.22 & 0.23 & 0.21 & 1.03 & 105.26 & 26.26 & 96.15 \\
\hline \multicolumn{8}{|c|}{ 2012/2013 season } \\
\hline 0 & 67.267 & 11.49 & 16.17 & 32.92 & 1023.58 & 737.36 & 286.22 \\
\hline 50 & 74.67 & 12.22 & 17.13 & 37.83 & 2023.62 & 1092.82 & 930.80 \\
\hline 100 & 82.32 & 13.41 & 18.23 & 44.17 & 3428.44 & 1322.24 & 2106.20 \\
\hline 150 & 86.65 & 13.80 & 18.42 & 45.92 & 3577.07 & 1474.20 & 2102.87 \\
\hline LSD $_{5 \%}$ & 0.93 & 0.16 & 0.16 & 0.59 & 116.81 & 18.48 & 84.11 \\
\hline
\end{tabular}

The present results agree with those of, Taha et al. (2011), who reported that, the application of magnetic treatment improved growth of pepper plant under salt condition. Such effect of magnetic field may be due to weakness bonds between certain ions and thought to be a major factor affecting on their activity in soil and plant. Obtained data agree those reported by Ismail et al. (2010), who reported that many benefits to crop growth can result from addition of the natural mineral product i.e., magnetic iron including improved soil structure, increased soil organic matter, improved water properties and become more energy and 
vigor and this known as "Magneto biology", improved water - holding capacity and cation exchange capacity, increasing water retention by soil and this helps plant growth, moderation of soil temperature, improved crop nutrition of macro and microelements. Moreover, the magnetic process separates all chlorine, toxic and harmful gases from soil which increases salt movement and solubility of nutrients. Behrouz \& Mojtaba (2011), pointed out that magnetic iron application had increased the ability of soil to get rid of salts. Also, It was resulted in a better assimilation of nutrients and fertilizer in plants during the vegetative period and increased crop production.

\section{Effect of biofertilization on yield and yield components}

It is interesting to note that, there were significant effects of all biofertilization treatments on yield and its components compared with inoculated soil, where the highest significant increase in yield and its components appeared under Rhizobium compared with the other treatments and control. Soil wheat plant inoculated with Rhizobium meliloti produced higher grain yield and its components than those inoculated with Pseudomonas fluorescence and the mixture of the two species of bacteria (Pseudomonas + Rhizobium). This may be due to Rhizobium is an important symbiotic for legumes but it plays an important role with non-legumes by producing growth hormones and different types of siderophores which established roots of non legumes also several mechanisms e.g., phytohormones production (Zahir et al., 2010). These results were true in the two growing seasons, (Table 7). This may be Rhizobium supply more plant hormones (auxin, cytokine, gibberellins...etc.) as reported by ElKased et al. (1996). These may be due to recycling nutrient elements as natural resources and increase in the amount of fixed nitrogen by plant and all over the soil and produce active substances which help in plant nutrient uptake. Zahir et al. (2010), reported similar findings of increased grain yield of wheat with biofertilization treatments. This is due to plant growth promoting rhizobacteria (PGPR) is a group of free-living bacteria that colonize the rhizosphere and exert a beneficial impact on plant health and soil fertility. PGPR can directly facilitate plant growth in several ways such as syntheses of phytohormones, siderophores production, solubilization of mineral phosphate and synthesis of the enzyme ACC-deaminase .

\section{Effect of the interaction between magnetic iron and biofertilization}

The effect of the interaction between different magnetite iron doses and biofertilization indicate significant increases in wheat yield due to the magnetic treatments under different biofertlization, especially the highest significant increase in yield characters obtained under the combined effect of Rhizobium meliloti and $100 \mathrm{~kg} / \mathrm{fed}$, of magnetic treatments compared with other treatments (Tables $8 \mathrm{a}$ and $8 \mathrm{~b}$ ). This increase in yield characters as a result of magnetite treatments may be due to that magnetic treatments improved capacity for nutrient and water uptake, providing better physical support to the developing shoot; better root growth and development in young seedlings might lead to better root systems throughout the lifetime of a plant (Lynch, 1995).

Egypt. J. Agron . 36, No.1 (2014) 
TABLE 7. Effect of different biofertilization on wheat yield and its components in two growing seasons.

\begin{tabular}{|c|c|c|c|c|c|c|c|}
\hline Treatment & $\begin{array}{l}\text { Plant } \\
\text { height } \\
(\mathrm{cm})\end{array}$ & $\begin{array}{l}\text { Spike } \\
\text { length } \\
(\mathrm{cm})\end{array}$ & $\begin{array}{c}\text { No. of } \\
\text { spikelets/ } \\
\text { spike }\end{array}$ & $\begin{array}{l}\text { 1000- } \\
\text { grains } \\
\text { weight } \\
\text { (g) }\end{array}$ & $\begin{array}{c}\text { Biological } \\
\text { yield } \\
(\mathrm{kg} / \mathrm{fed})\end{array}$ & $\begin{array}{c}\text { Grain } \\
\text { yield } \\
\text { (kg/fed) }\end{array}$ & $\begin{array}{c}\text { Straw } \\
\text { yield } \\
\text { (kg/fed) }\end{array}$ \\
\hline \multicolumn{8}{|c|}{ 2011/2012 season } \\
\hline Conrol & 69.18 & 11.38 & 16.34 & 34.58 & 992.01 & 512.78 & 479.23 \\
\hline $\begin{array}{l}\text { Pseudomonas } \\
\text { fluorescence }\end{array}$ & 75.46 & 12.75 & 17.62 & 40.92 & 1818.62 & 1179.70 & 638.92 \\
\hline $\begin{array}{l}\text { Rhizobium } \\
\text { meliloti }\end{array}$ & 88.16 & 14.08 & 18.84 & 46.00 & 4424.51 & 1697.41 & 2727.10 \\
\hline $\begin{array}{l}\text { Mix } \\
\text { (Pseud.+Rizo.) }\end{array}$ & 86.87 & 14.02 & 18.75 & 44.25 & 4214.13 & 1526.37 & 2687.76 \\
\hline $\mathrm{LSD}_{5 \%}$ & 1.33 & 0.18 & 0.27 & 1.65 & 94.52 & 20.89 & 62.01 \\
\hline \multicolumn{8}{|c|}{ 2012/2013 season } \\
\hline Control & 67.83 & 11.0 & 16.13 & 33.17 & 913.77 & 468.98 & 444.79 \\
\hline $\begin{array}{l}\text { Pseudomonas } \\
\text { fluorescence }\end{array}$ & 74.08 & 12.24 & 17.38 & 38.75 & 1668.11 & 1112.97 & 555.14 \\
\hline $\begin{array}{l}\text { Rhizobium } \\
\text { meliloti }\end{array}$ & 85.26 & 13.93 & 18.28 & 45.33 & 3776.18 & 1594.71 & 2181.47 \\
\hline $\begin{array}{l}\text { Mix } \\
\text { (Pseud.+Rizo.) }\end{array}$ & 80.73 & 13.74 & 18.15 & 43.58 & 3694.65 & 1449.97 & 2244.68 \\
\hline $\mathrm{LSD}_{5 \%}$ & 1.12 & 0.23 & 0.27 & 0.70 & 274.46 & 18.31 & 43.12 \\
\hline
\end{tabular}

TABLE 8a. Effect of interaction between magnetic iron and biofertilization on wheat yield and its components .

\begin{tabular}{|c|c|c|c|c|c|c|c|c|}
\hline \multicolumn{2}{|c|}{$\mathrm{N}_{\text {Treatments }}$ Characters } & $\begin{array}{l}\text { Plant } \\
\text { height } \\
(\mathrm{cm})\end{array}$ & $\begin{array}{l}\text { Spike } \\
\text { length } \\
\text { (cm) }\end{array}$ & \begin{tabular}{|c|} 
No. of \\
spikelets/ \\
spike
\end{tabular} & $\begin{array}{c}1000- \\
\text { grains } \\
\text { weight }(\mathrm{g})\end{array}$ & $\begin{array}{c}\text { Biological } \\
\text { yield } \\
\text { kg/fed }\end{array}$ & $\begin{array}{l}\text { Grain } \\
\text { yield } \\
\text { kg/fed }\end{array}$ & $\begin{array}{c}\text { Straw } \\
\text { yield } \\
\text { kg/fed }\end{array}$ \\
\hline Biofertlization & \begin{tabular}{|l|}
$\begin{array}{l}\text { Magnetic } \\
\text { iron } \\
(\mathrm{kg} / \mathrm{fed})\end{array}$ \\
\end{tabular} & \multicolumn{7}{|c|}{ 2011/2012 season } \\
\hline \multirow[t]{4}{*}{ Control } & 0 & 60.77 & 10.4 & 15.73 & 25.33 & 798.47 & 155.37 & 643.1 \\
\hline & 50 & 67.73 & 11.2 & 16.10 & 33.00 & 924.43 & 357.47 & 566.96 \\
\hline & 100 & 73.07 & 11.4 & 16.43 & 38.00 & 1035.90 & 642.57 & 393.33 \\
\hline & 150 & 75.17 & 12.2 & 17.10 & 42.00 & 1209.23 & 895.73 & 313.50 \\
\hline \multirow{4}{*}{$\begin{array}{l}\text { Pseudomonas } \\
\text { fluorescence }\end{array}$} & 0 & 66.20 & 11.3 & 16.50 & 35.00 & 904.30 & 532.9 & 371.40 \\
\hline & 50 & 73.90 & 12.53 & 17.53 & 39.67 & 1300.73 & 1017.67 & 283.06 \\
\hline & 100 & 79.20 & 13.47 & 18.10 & 43.33 & 2041.10 & 1339.9 & 701.20 \\
\hline & 150 & 83.27 & 13.70 & 18.33 & 45.67 & 3058.33 & 1528.33 & 1530.00 \\
\hline \multirow{4}{*}{\begin{tabular}{|l} 
Rhizobium \\
meliloti
\end{tabular}} & 0 & 70.43 & 12.23 & 17.07 & 36.67 & 1423.57 & 1122.40 & 301.17 \\
\hline & 50 & 87.37 & 13.63 & 18.60 & 43.33 & 3438.93 & 1751.77 & 1687.16 \\
\hline & 100 & 98.13 & 15.33 & 19.93 & 53.00 & 6666.90 & 1959.87 & 4707.03 \\
\hline & 150 & 96.73 & 15.10 & 19.77 & 51.00 & 6168.63 & 1955.60 & 4213.03 \\
\hline \multirow{4}{*}{\begin{tabular}{|l|} 
Mix \\
$($ Pseud.+Rizo. $)$ \\
\end{tabular}} & 0 & 76.33 & 12.93 & 17.20 & 38.33 & 1489.97 & 1167.73 & 322.24 \\
\hline & 50 & 82.37 & 13.43 & 18.67 & 41.33 & 3675.60 & 1454.07 & 2225.53 \\
\hline & 100 & 93.63 & 14.63 & 19.60 & 47.00 & 5286.60 & 1645.47 & 3641.13 \\
\hline & 150 & 95.17 & 15.07 & 19.80 & 50.33 & 6404.37 & 1838.20 & 4566.17 \\
\hline \multicolumn{2}{|l|}{ LSD $_{5 \%}$} & 2.663 & 0.496 & 0.456 & 2.027 & 295.274 & 57.501 & --- \\
\hline
\end{tabular}


TABLE 8b. Effect of interaction between magnetic iron and biofertilization on wheat yield and its components.

\begin{tabular}{|c|c|c|c|c|c|c|c|c|}
\hline Treatments & 1aracters & $\begin{array}{c}\text { Plant } \\
\text { height } \\
(\mathrm{cm})\end{array}$ & $\begin{array}{l}\text { Spike } \\
\text { length } \\
(\mathrm{cm})\end{array}$ & $\begin{array}{c}\text { No. of } \\
\text { spikelets/ } \\
\text { spike }\end{array}$ & $\begin{array}{l}\text { 1000- } \\
\text { grains } \\
\text { weight } \\
\text { (g) }\end{array}$ & $\begin{array}{c}\text { Biological } \\
\text { yield } \\
\text { kg/fed }\end{array}$ & $\begin{array}{c}\text { Grain } \\
\text { yield } \\
\text { kg/fed }\end{array}$ & $\begin{array}{c}\text { Straw } \\
\text { yield } \\
\text { kg/fed }\end{array}$ \\
\hline Biofertlizer & $\begin{array}{c}\text { Magneti } \\
\text { c iron } \\
(\mathrm{kg} / \text { fed })\end{array}$ & \multicolumn{7}{|c|}{ 2011/2012 season } \\
\hline \multirow[t]{4}{*}{ Control } & 0 & 59.84 & 9.80 & 15.47 & 24.33 & 710.60 & 140.40 & 570.20 \\
\hline & 50 & 65.77 & 10.80 & 16.03 & 32.00 & 809.37 & 322.47 & 486.90 \\
\hline & 100 & 71.03 & 11.47 & 16.13 & 36.33 & 946.67 & 593.70 & 352.97 \\
\hline & 150 & 74.70 & 11.93 & 16.90 & 40.00 & 1170.43 & 819.37 & 351.33 \\
\hline \multirow[t]{4}{*}{$\begin{array}{l}\text { Pseudomonas } \\
\text { fluorescence }\end{array}$} & 0 & 65.87 & 11.03 & 16.10 & 33.67 & 960.70 & 276.23 & 684.47 \\
\hline & 50 & 72.73 & 11.97 & 17.23 & 36.67 & 1174.13 & 952.13 & 222.00 \\
\hline & 100 & 77.27 & 12.77 & 17.97 & 41.00 & 1870.70 & 1241.81 & 628.89 \\
\hline & 150 & 80.47 & 13.20 & 18.20 & 43.67 & 2866.90 & 1481.70 & 1385.20 \\
\hline \multirow[t]{4}{*}{$\begin{array}{l}\text { Rhizobium } \\
\text { meliloti }\end{array}$} & 0 & 69.77 & 12.10 & 16.40 & 36.33 & 1246.50 & 978.00 & 368.50 \\
\hline & 50 & 83.10 & 12.93 & 17.90 & 41.33 & 2808.77 & 1695.10 & 1113.67 \\
\hline & 100 & 96.17 & 14.90 & 19.57 & 53.00 & 5925.50 & 1880.43 & 4045.07 \\
\hline & 150 & 92.00 & 15.03 & 19.23 & 50.67 & 5123.97 & 1825.30 & 3298.67 \\
\hline \multirow[t]{4}{*}{$\begin{array}{l}\text { Mix } \\
\text { (Pseud.+Rizo.) }\end{array}$} & 0 & 73.60 & 13.03 & 16.70 & 37.33 & 1376.53 & 1054.83 & 321.70 \\
\hline & 50 & 77.10 & 13.17 & 17.33 & 41.33 & 3302.20 & 1401.57 & 1900.63 \\
\hline & 100 & 84.80 & 14.50 & 19.23 & 46.33 & 4952.90 & 1573.03 & 3379.87 \\
\hline & 150 & 87.43 & 15.03 & 19.33 & 49.33 & 5146.97 & 1770.43 & 3376.54 \\
\hline \multicolumn{2}{|l|}{$\operatorname{LSD}_{5 \%}$} & 2.041 & 0.345 & 0.356 & 1.304 & 255.826 & 40.473 & ----- \\
\hline
\end{tabular}

Biofertilization like Rhizobium supplemented $75 \%$ (100 kg iron ore /fed) of the recommended dose of magnetic iron in wheat which not only reduce the chemical fertilizers but also equalized the yield of wheat when compared with $100 \%$ (150 kg iron /fed) of the recommended dose of magnetic iron alone to improve wheat utilization of fertility status (Hasabo, 2006). AbdElbary et al. (2007), reported that the application of iron nutrient solution, magnetic iron, metal compound fertilizer and liquid culture of the bacteria, suppressed several species of plant-parasitic nematodes and improved the growth of the host crops, and changes in the physiological and the chemical properties of the soil (Zahir et al., 2010).

\section{Chemical composition of wheat grain yield}

Effect of magnetic iron on chemical composition of wheat grain yield

Data indicated in Fig. $1 \mathrm{a}$ and $1 \mathrm{~b}$ show that the effect of magnetic iron on percentage of $\mathrm{K}, \mathrm{Na}, \mathrm{K} / \mathrm{Na}$ ratio, $\mathrm{N}$ and protein content in wheat grain were significant in the two growing seasons, except those of sodium content in the second season. Magnetic treatments showed gradual and significant increases in $\mathrm{N}$ and $\mathrm{K} \mathrm{K} / \mathrm{Na}$, protein content in the two growing seasons, except sodium content of wheat grain compared with control in both seasons. Highest accumulation was obtained under $(150 \mathrm{~kg} / \mathrm{fed})$ magnetite dose. These may be due to the role of iron which was important in the activation of several enzyme

Egypt. J. Agron . 36, No.1 (2014) 
systems in plants including: fumaric hydrogenase, catalase, oxidase and cytochrome. A shortage of $\mathrm{Fe}$ also impairs chlorophyll production. Iron is thought to be associated with the synthesis of chloroplastic protein.
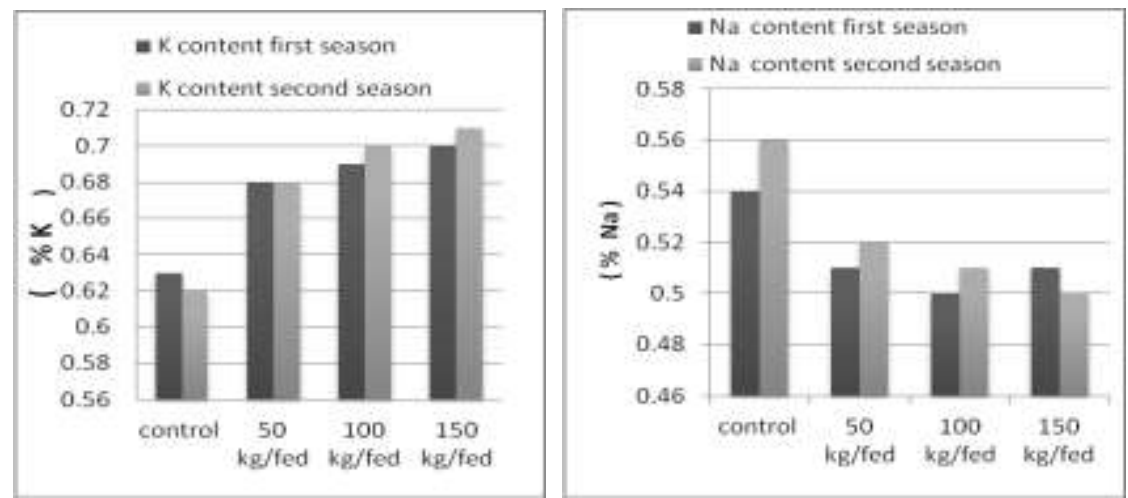

Fig. 1a. Effect of magnetic iron on $\mathrm{K}$ and $\mathrm{Na}$ contents of wheat grain in two growing seasons.
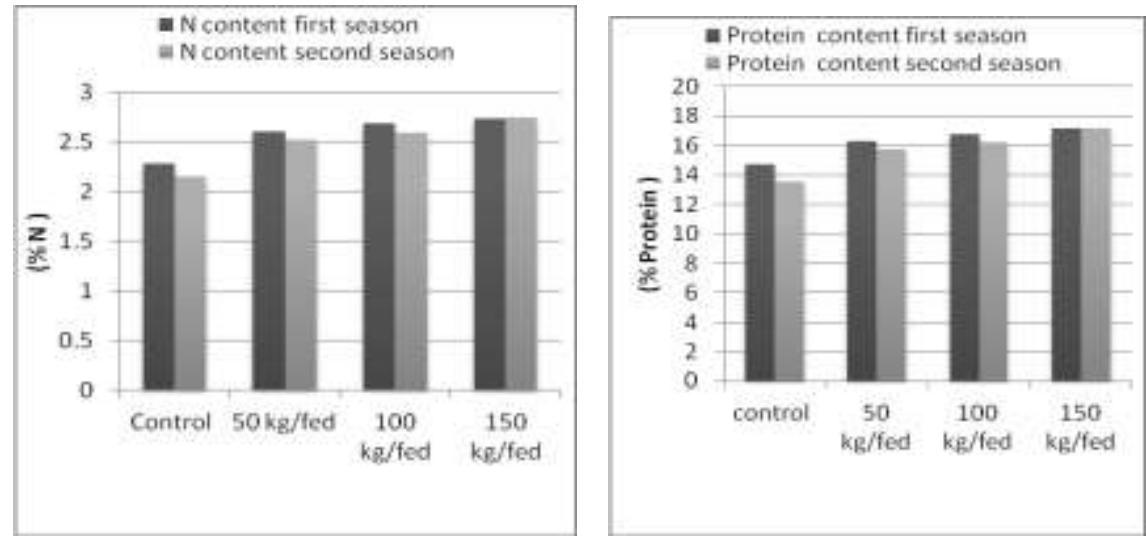

Fig. 1b. Effect of magnetic iron on $\mathbf{N}$ and protein content of wheat grain in two growing seasons.

The increase in $\mathrm{N}$ and $\mathrm{K}$ concentrations with magnetic treatments may be due to its effect on adsorption of $\mathrm{N}$ and $\mathrm{K}$ from soil colloidal complex and thus increasing its availability to plants. Also, magnetic treatments improve availability, uptake, assimilation and mobilization of these nutrients within the plant system (Maheshwari, 2009). These results were in line with those obtained by Mansour (2007) who reported that there were gradual increments in nitrogen, phosphorus, potassium, calcium and iron concentration in cauliflower leaves with increasing magnetite levels. Moreover, Maurya et al. (1993) and Krzywy \& Gowacka (1998) reported increase in N content with increasing magnetite doses. 
Effect of the biofertilization on chemical composition of wheat grain yield

Results in Fig. 2a and 2b, show that the effect of biofertilization on $\mathrm{K}, \mathrm{Na}$, $\mathrm{K} / \mathrm{Na}$ ratio, $\mathrm{N}$ and protein content in grain of wheat were significant in the two growing seasons. Rhizobium was superior to other treatments in all characters in the two growing seasons except $\mathrm{K}$ content which was not significant in the first growing season. The grain analyses reveal that the uptake of the important nutrients of $\mathrm{N}$ and protein were improved by varying degrees. Such improvement in the chemical composition of both grain and straw has an impact on their nutritional value for human and animal consumption. Though the application of Rhizobium proved superiority compared with other sources in terms of high yield and plant uptake of essential elements. These results agreed with those obtained by Dakora (2003), who found that plant inoculation with Rhizobium for example, promoted greater uptake of $\mathrm{NO}_{3}^{-}, \mathrm{K}^{+}$and $\mathrm{H}_{2} \mathrm{PO}_{4}{ }^{-}$in corn, sorghum, and wheat, leading to higher crop yields. Rhizobia may produce various metabolites such as auxins, cytokinins, riboflavinand vitamins.
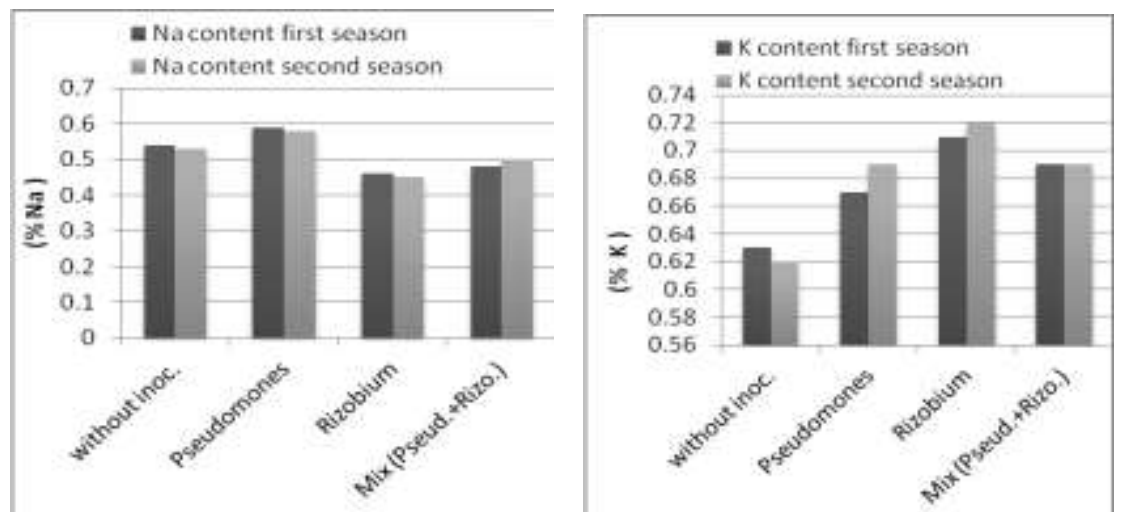

Fig. 2a. Effect of biofertilization on $\mathrm{Na}$ and $\mathrm{K}$ contents of wheat grain in two growing seasons.
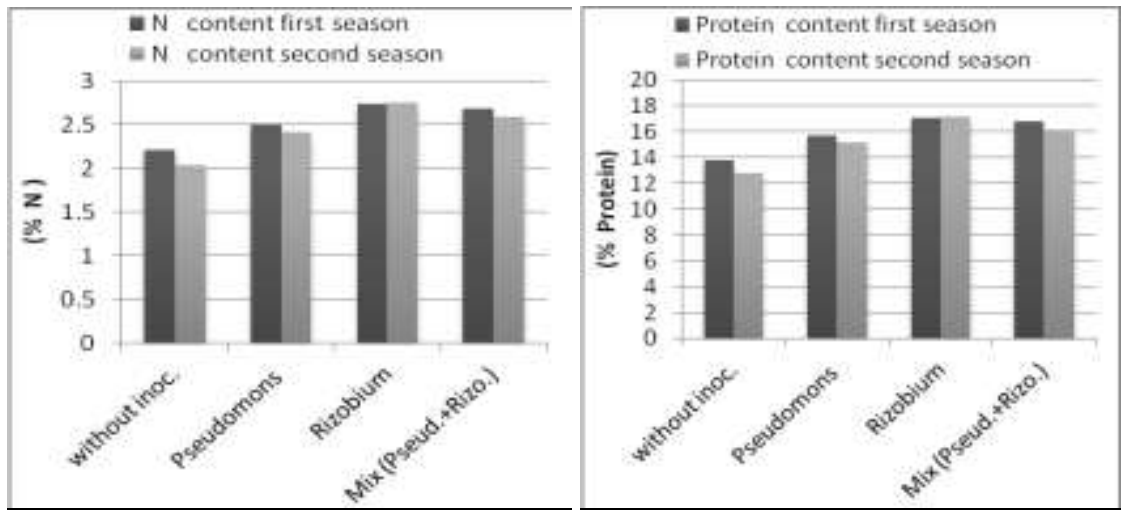

Fig. 2b. Effect of biofertilization on $\mathrm{N}$ and protein content of wheat grain in two growing seasons.

Egypt. J. Agron . 36, No.1 (2014) 
Effect of the interaction between magnetic iron and biofertilization on chemical composition of grain yield

Results in Table 9, show that the effect of interaction between magnetic iron and biofertilization on the percentage of $\mathrm{K}, \mathrm{Na}, \mathrm{K} / \mathrm{Na}$ ratio, $\mathrm{N}$ and protein content in grain of wheat in the two growing seasons, was significant, except $\mathrm{K}$ content of grain in the second season. Maximum values of the aforementioned criteria were obtained in the tissue of wheat grain fertilized by $150 \mathrm{~kg} / \mathrm{fed}$ and inoculated with Rhizobium. These may be due to the increase of nitrogen content in grain supply by Rhizobium.

TABLE 9. Effect of the interaction between magnetic iron and biofertilization (2011/20112 and 2012/2013 seasons) .

\begin{tabular}{|c|c|c|c|c|c|c|c|c|c|c|c|}
\hline \multicolumn{2}{|c|}{ Conten } & \multicolumn{2}{|c|}{$\begin{array}{c}\mathbf{K} \\
(\%)\end{array}$} & \multicolumn{2}{|c|}{$\begin{array}{l}\mathrm{Na} \\
(\%)\end{array}$} & \multicolumn{2}{|c|}{$\mathrm{K} / \mathrm{Na}$ ratio } & \multicolumn{2}{|c|}{$\begin{array}{c}\mathrm{N} \\
(\%)\end{array}$} & \multicolumn{2}{|c|}{\begin{tabular}{|c} 
Protein content \\
$\%$ \\
\end{tabular}} \\
\hline Biofertlization & $\begin{array}{c}\text { Magnetic } \\
\text { Iron } \\
\text { (kg/fed) }\end{array}$ & $1^{s t}$ & $2^{n d}$ & $1^{\text {st }}$ & $2^{n d}$ & $1^{s t}$ & $2^{\text {nd }}$ & $\mathbf{1}^{s t}$ & $2^{\text {nd }}$ & $1^{s t}$ & $2^{n d}$ \\
\hline \multirow[t]{4}{*}{ Control } & 0 & 0.63 & 0.64 & 0.54 & 0.53 & 1.17 & 1.21 & 2.31 & 1.92 & 14.44 & 12.00 \\
\hline & 50 & 0.63 & 0.64 & 0.53 & 0.52 & 1.19 & 1.23 & 2.38 & 2.00 & 14.88 & 12.50 \\
\hline & 100 & 0.64 & 0.65 & 0.52 & 0.51 & 1.23 & 1.27 & 2.39 & 2.25 & 14.94 & 14.06 \\
\hline & 150 & 0.65 & 0.65 & 0.51 & 0.51 & 1.27 & 1.27 & 2.40 & 2.30 & 15.00 & 14.38 \\
\hline \multirow[t]{4}{*}{$\begin{array}{l}\text { Pseudomonas } \\
\text { fluorescence }\end{array}$} & 0 & 0.64 & 0.64 & 0.53 & 0.52 & 1.21 & 1.23 & 2.40 & 2.25 & 15.06 & 14.06 \\
\hline & 50 & 0.65 & 0.65 & 0.51 & 0.50 & 1.27 & 1.30 & 2.41 & 2.43 & 14.94 & 15.19 \\
\hline & 100 & 0.66 & 0.67 & 0.50 & 0.49 & 1.32 & 1.37 & 2.48 & 2.45 & 15.50 & 15.31 \\
\hline & 150 & 0.67 & 0.67 & 0.49 & 0.49 & 1.37 & 1.37 & 2.50 & 2.42 & 15.63 & 15.13 \\
\hline \multirow[t]{4}{*}{$\begin{array}{l}\text { Rhizobium } \\
\text { meliloti }\end{array}$} & 0 & 0.64 & 0.65 & 0.51 & 0.51 & 1.25 & 1.27 & 2.41 & 2.45 & 15.06 & 15.31 \\
\hline & 50 & 0.67 & 0.66 & 0.49 & 0.48 & 1.16 & 1.38 & 2.49 & 2.51 & 15.56 & 15.69 \\
\hline & 100 & 0.68 & 0.68 & 0.48 & 0.47 & 1.42 & 1.47 & 2.56 & 2.63 & 16.00 & 16.44 \\
\hline & 150 & 0.69 & 0.69 & 0.47 & 0.46 & 1.47 & 1.50 & 2.68 & 2.72 & 16.75 & 17.00 \\
\hline \multirow[t]{4}{*}{$\begin{array}{l}\text { Mix } \\
\text { (Pseud.+Rizo.) }\end{array}$} & 0 & 0.64 & 0.65 & 0.51 & 0.50 & 1.25 & 1.30 & 2.43 & 2.46 & 15.19 & 15.38 \\
\hline & 50 & 0.66 & 0.66 & 0.49 & 0.50 & 1.35 & 1.32 & 2.53 & 2.50 & 15.81 & 15.63 \\
\hline & 100 & 0.67 & 0.68 & 0.48 & 0.47 & 1.39 & 1.45 & 2.56 & 2.58 & 16.00 & 16.13 \\
\hline & 150 & 0.68 & 0.69 & 0.47 & 0.47 & 1.45 & 1.47 & 2.68 & 2.60 & 16.75 & 16.25 \\
\hline \multicolumn{2}{|l|}{$\mathrm{LSD}_{5 \%}$} & 0.01 & Ns & 0.02 & 0.04 & 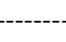 & -- & 0.01 & 0.01 & 0.07 & 0.07 \\
\hline
\end{tabular}




\section{Conclusions}

The application of magnetic iron and Rhizobium meliloti have profoundly alleviated salinity effects and improved performance by increasing wheat productivity as evidenced by the application of magnetic iron at $100 \mathrm{~kg} / \mathrm{fed}$ with Rhizobium melilotito reduce soil salinity for minimizing the hazard of salts on wheat productivity under saline stress conditions.

\section{References}

Abd El-Al, F.S. (2003) Different nitrogen sources and magnetic iron addition as affected the productivity of eggplant (Solanum melogena L.) plant. J. Agric. Sci. Mansoura Univ. 28(4), 2903-2916.

Abd El Ghany, Bouthaina F. (1994) Effect of biofertilization and chemical fertilizers on soil microbial properties and fodder production under calcareous soil conditions. Deser Inst. Bull., Egypt, 44(2), 247-262.

Abd El-Ghany, B.F., Khalil, K.W., El-Sersawy, M.M. and Awadallah, S.Y. (1997) Improvement of Wadi Sudr soil properties using modern bio-organic techniques and their effects on desertification combat and barley production. Desert Ins. Bull. Egypt. 47(1), 69-100.

Abd-Elbary, N.A., Eissa, M.F.M., Yassin, M.Y., Ismail, A.E., Badr, U.M. and Soliman, G.M. (2007) Effect of a wild type and three different mutants of chitinolytic bacteria, Bacillus thuringiensis by U.V. irradiation on viability of Meloidogyne incognita eggs under laboratory conditions. J. Agric. Sci. Mansoura Univ. 32, 9217-9226.

Al- Ansari, F.M. (2003) Salinity tolerance during germination in two arid- land varieties of wheat (Triticum aestivum L.). Seed Science and Technology, 31(3), 597- 603.

Anandaraj, B. and Leema Rose Delapierre, A. (2010) Studies on influence of bioinoculants (Pseudomonas fluorescens, Rhizobium sp., Bacillus megaterium) in green gram. J. Biosci. Tech. 1 (2), 95-99.

Anderson, J. P. E. (1982) Soil respiration. In: "Methods of Soil Analysis", part 2, $2^{\text {nd }}$ ed., A. L. Page, R. H. Miller and D. R. Keeney (Ed.),n pp.837-871. Madison, Wisc.:ASA and SSS.

Anonymous (2006) Annual Report. El-Ahram Company for Mining and Natural Fertilizers, Giza, Egypt.

Antoun, H. and Prevost, D. (2000) PGPR activity of Rhizobium with nonleguminous plants. Available on http://www. ag.auburn. edu/argentina/ pdfmanuscripts/ tableofcontents. pdf. (Assessed on: 30-09).

A.O.A.C. (1995) "Official Methods of Analysis of The Association of Official Analytical Chemists" $15^{\text {th }}$ ed. Published by the association of official analytical chemists. INC. Suite 400, 200 Wlson Boulevard- Arligton Virginia 22201 USA. Pp. 69-90.

Egypt. J. Agron . 36, No.1 (2014) 
Bangar, K.C., Yadav, K.S. and Mishra, M.M. (1985) Transformation of rock phosphate during composting and the effect of humic acid. Plant Soil, 85, 259- 266.

Barrau, E.M. and Berg, W.A. (1977) Pyrite and pyritic mill tailings as a source of iron in a calcareous iron-deficient soil. Soil Sci. Soc. Am. J. 41, 385-388.

Behrouz, M. and Mojtaba, K. (2011) Effect of magnetized water and irrigation water salinity on soil moisture distribution in trickle irrigation. J. Irrigation Drainage Eng. 137, 398 .

Bergey's Manual of Determinative Bacteriology (1994) John G Hol, Noel R. Kriey, Peter H.A. Sneath, James T. Staley T.Williams (Ed.) $\left(9^{\text {th }}\right.$ ed.) Williams and Wilkins, Baltimore, London.

Dakora, F.D. (2003) De fining new roles for plant and rhizobial molecules in sole and mixed plant cultures involving symbiotic legumes. New Phytol. 58, 39-49.

De Freitas, J.R., Banerjee, M.R. and Germida, J.J. (1997) Phosphate solubilizing rhizobacteria enhance the growth and yield but not phosphorus uptake of Canola (Brassica napus L.). Biol. Fertil. Soils, 24, 358-364.

De Souza, A. (2005) Increase of vegetable productivity cultivated under organic conditions and small extensions by pre-sowing magnetic treatment of seeds. Agricultural Research Institute «Jorge Dimitrov», Bayamo,Cuba.

El-Kased, F. A., Kamh R. N. and Abd-El-Ghany, F. (1996) Wheat response to bioand mineral nitrogen fertilized in newly reclaimed sandy soil. Desert Inst. Bull., Egypt, 49 (2), 373-386.

El-Saidy, Aml E.A. and Abd El-Hai, K.M. (2011) Alleviation of peanut seed deterioration during storage using biotic and abiotic agents. Res. J. Seed Sci. ISSN 1819-3552/Dol: 10.3923/rjss, p. 1-13.

Esitken, A. and Turan, M. (2004) Alternating magnetic field effects on yield and plant nutrient element composition of strawberry (Fragaria x ananassa cv. camarosa). Acta Agric. Scand., Sect. B, Soil and Plant Sci. 54, 135-139.

Fatima, Z., Zia, M. and Chaudhary, M.F. (2006) Effect of Rhizobium strains and phosphorus on growth of soybean (Glycine max) and survival of Rhizobium and $\mathrm{P}$ solubilizing bacteria. Pak. J. Bot. 38, 459-464.

Food and Agriculture Organization of the United Nation (2005) Land and Plant Nutrition Management Service Land and Water Development Division.

Food and Agriculture Organization of the United Nation (2008) Land and plant nutrition management service. http://WWW.Fao.Org/ag/agl/agll/spush.

Guerinot, M.L. (1991) Iron uptake and metabolism in the rhizobia/legume symbioses. Plant Soil, 130,199-209. 
Hafeez, F.Y., Naeem, F.I., Naeem, R., Zaidi, A.H. and Malik, K.A. (2005) Symbiotic effectiveness and bacteriocin production by Rhizobium leguminosarum bv. Viciae isolated from agriculture soils in Faisalabad. Environ. Exper. Bot. 54,142-147.

Hasabo, S.A. (2006) Management of the root-lesion nematode, Pratylenchus zeae on sugar cane by some organic and non-organic soil amendments. Minufiya. J. Agric. Res. 31, 207-219.

Ismail, A.E., Soliman, S.S., Abd El-Moniem, E.M., Awaad, M.S. and Rashad, A.A. (2010) Effect of magnetic iron ore, metal compound fertilizer and bio-NK in controlling root-knot nematode of Grapevine in a newly reclaimed area of Egypt. Pak. J. Nematol. 28(2), 307-328.

Jarlier, V., Fosse, T. and Philipon, A. (1996) Antibiotic susceptibility in aerobic Gramnegative bacilli isolated in intensive care units in 39 French teaching hospitals (ICU study). Intensive Care Mod. 22, 1057-1065.

Kloepper, J. W. and Beauchamp, C. J. (1992) A review of issues related to measuring colonization of plant roots by bacteria. Can. J. Microbiol. 38,1219-1232.

Krzywy, E. and Gowacka, A. (1998) Studies on the influence of iron (П) sulphate (VI) heptahydrate and multicomponent fertilizers on yield and quality. Part II. Small radish cv. sopel lodu. Folia Universitatis Agriculture Stetinensis Agricultural, 72,163-166. C.a. Cab Abst., 1999.

Leonardos, O.H., Theodora, S.H. and Assad, M.L. (2000) The use of ground rocks in laterite systems: an improvement to the use of conventional soluble fertilizers. Nutr. Cycling Agroecosyst, 56,3-9.

Lynch, J. (1995) Root architecture and plant productivity. Plant Physiol. 109, 7-13.

Maheshwari, L.B. (2009) Magnetic treatment of irrigation water: evaluation of its effects on vegetable crop yield and water productivity. Ph.D Thesis. University of Western Sydney, School of Environ. and Agriculture.

Mansour, E.R. (2007) Effect of some culture practices on cauliflower tolerance to salinity under Ras Suder conditions. MS Thesis. Fac. Agric., Horticulture Dept. Ain Shams Univ., Egypt.

Mass, E.V. and Hooffman, G.T. (1977) Crop salt tolerance current assessment. J. Irrig. Drainage Division. ASCEIRZ: pp.115-134.

Maurya, B.R., Kishar, K. and Ram, P.C. (1993) Effect of iron and molybdenum on curd bean. Journal of Maharashtra Agricultural Universities, 18(1),128.

Mayak, S., Tipora, T. and Glick, B.R. (2004) Plant growth-promoting bacteria confer resistance in tomato plants to salt stress. Plant Physiol. 42, 565-572.

Meyer, J.M. (2000) Pyoverdines: pigments, siderophores and potential taxonomic markers of fluorescent Pseudomonas sp. Arch.Microbiol. 174, 135-142. 
Meyer, J. M., Azelvandre, P. and Georges, C. (1992) Iron metabolism in Pseudomonas: salicylic acid, a siderophore of Pseudomonas fluorescens CHAO. Biofactors, 4, 23-27.

Mesut, Ç.K., Önder, T., Metin, T. and Burcu, T. (2010) Phosphorus and humic acid application alleviate salinity stress of pepper seedling. African Journal of Biotechnology, 9(36), 5845-5851.

Murray, P. R., Baron, E. J., Jorgensen, J. H., Pfaller, M. A. and Yolken, R. H. (2003) "Manual of Clinical Microbiology", (Ed.), $8^{\text {th }}$ ed., ASM, Washington, D.C.

Nautiyal, C.S. (1999) An efficient microbiological growth medium for screening phosphate solubilizing microorganisms. FEMS. Microbiology. Letters. 170, $265-270$.

Page (1982) Plessner O., Klapatch T., Guerinot M.L. (1993) Siderophore utilization by Bradyrhizobium japonicum . Appl. Environ. Microbiol. 59,1688-1690.

Podleśny, J., Pietruszewski, S. and Podleśna, A. (2005) Influence of magnetic stimulation of seeds on the formation of morphological features and yielding of the pea. International Agrophysics 19, 61-68.

Reeves, M., Pine, L., Neilands, J. B. and Bullows, A. (1983) Absence of siderophore activity in Legionella sp. grown in iron deficient media. Journal Bacteriology, 154, 324-329.

Rizzolo, A.C., Baldo, J. and Polesello, A. (1993) Application of high performance liquid chromatography to the analysis of niacin and biotin in Italian almond cultivars, $J$. of Chromatoghraphy, 553(1-2).

Sharma, S.K., Dixit, R.S. and Tripathi, H.P. (2003) Water management in potato (Solanum tuberosum). Indian Journal of Agronomy, 38(1), 68-73.

Snedecor, G.W. and Cochran, W.G. (1990) "Statistical Methods" ( $7^{\text {th }}$ ed.), Iowa State University Press, Ames, Iowa, USA, 507 pp.

Stoltzfus, J.R., Malarvithi, P.P., Ladha, J.K. and Bruijn, F. D. (1997) Isolation of endophytic bacteria from rice and assessment of their potential for supplying rice with biologically fixed nitrogen. Plant Soil, 194, 25-36.

Sudhakar, P.C., Chandel, R.S. and Kalyan, S. (2002) Effect of sulphar, iron and silicon on the growth and yield of irrigated mustard. Annals of Agricultural Research, 23(3), 483-485.

Taha, B.A., Khalil, Soha, E., and Khalil, A.M., (2011) Magnetic treatments of Capsicum annuum L. grown under saline irrigation conditions. Journal of Applied Sciences Research, 7(11), 1558- 1568.

Visser, S. and Dennis, P. (1992) Soil biological criteria as indications of soil quiantity:Soil microorganisms. American J. of Alternative Agriculture, 7, 33-37.

Viviene, N., Matiru and Dakora, F.D. (2004) Potential use of rhizobial bacteria as promoters of plant growth for increased yield in landraces of African cereal crops. African Journal of Biotechnology, 3 (1), 1-7. 
Wiehe, W. and Höflich, G. (1995) Survival of plant growth promoting rhizosphere bacteria in the rhizosphere of different crops and migration to non-inoculated plants under field conditions in north-east Germany. Microbiol. Res. 150, 201-206.

Yadav, E., Pathak, D. V., Sharma, S. K. , Kumar, M. and Sharma, P. K. (2007) Isolation and characterization of mutants of Pseudomonas maltophila PM-4 altered in chitinolytic activity and antagonistic activity against root rot pathogens of clusterbean (Cyamopsis tetragonoloba). Indian J. of Microbiology, 47, 64-71.

Yildirim, E., Taylor, A.G. and Spittler, T.D. (2006) Ameliorative effects of biological treatments on growth of squash plants under salt stress. Sci. Hortic.111,1-6.

Zahir, Z.A., Yasin, H.M., Naveed, M., Anjum, M.A. and Khalid, M. (2010) LTryptophan application enhances the effectiveness of Rhizobium inoculation for improving growth and yield of mung bean [Vigna radiate (L.) Wilczek]. Pak. J. Bot. 42, 1771-1780.

Zhu, J.K. (2001) Plant Salt Tolerance. Trends Plant Sci. 6, 66-71.

(Received 7/4/2014

accepted 29/6/2014) 


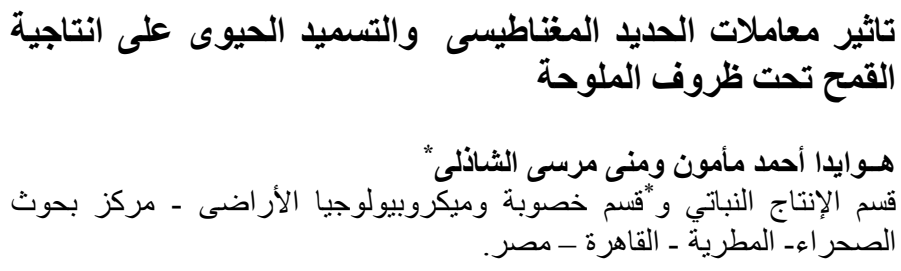

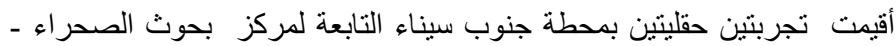

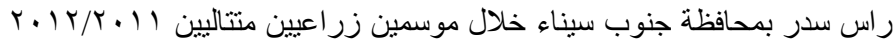

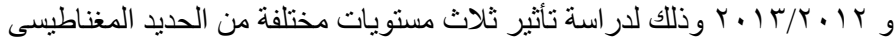

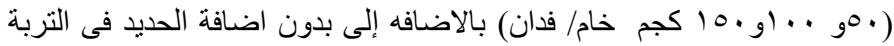

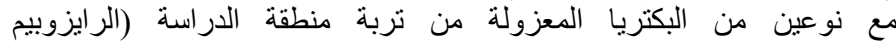

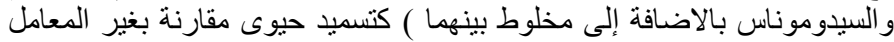

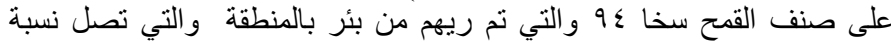

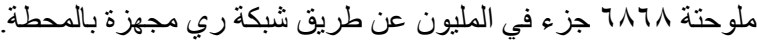
أوضحت الدراسة النتائج التالية:

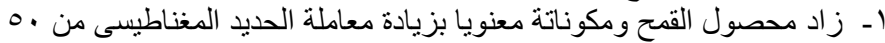

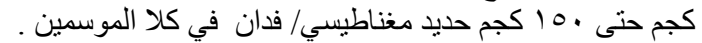

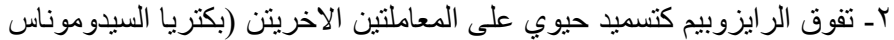

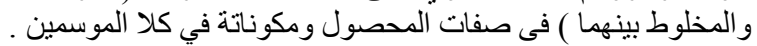

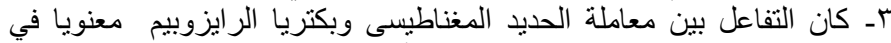

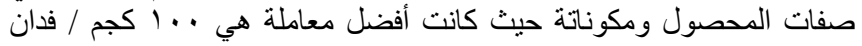

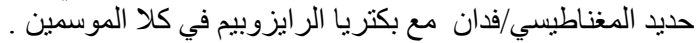

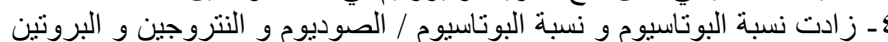

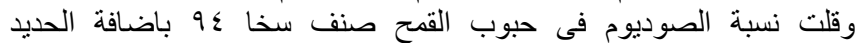

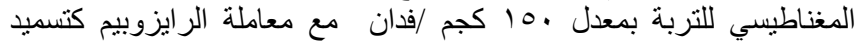

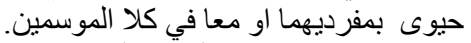

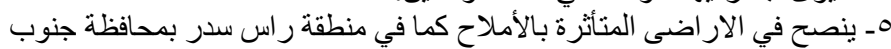

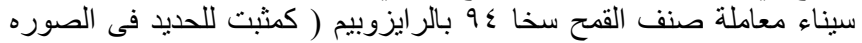

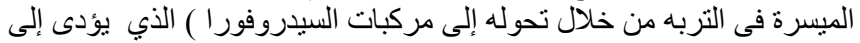

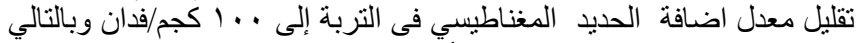

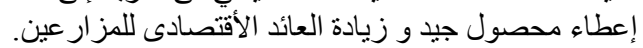

